\title{
PENGEMBANGAN ASPEK BAHASA MELALUI DARING SELAMA MASA PANDEMI COVID 19 DI RA NURUL HUDA
}

\author{
Ance Cahyati \\ Program Studi : Manajemen Pendidikan Islam, Universita Islam Bandung \\ Email : cahyati2ance@yahoo.co.id \\ DOI: \\ Accepted:. Approved:. Published:
}

\begin{abstract}
Covid 19 pandemic has become a separate problem that affects all aspects of human life throughout the world, including the world of education. When implementing PSBB and establishing PJJ by the government, educational institutions starting from the lowest level up to tertiary institutions must be able to implement these provisions without giving up students' rights to receive teaching. One solution that can be done during this pandemic is the use of diverse social media. Associated with multiple intelligences of children sparked by Howard Gardner, that one of the children's language intelligence, will be accompanied by cognitive intelligence. So it can be said that the application of PJJ must be adjusted to the indicators of achievement according to its age. various types of models and methods can be done, so that the growth and development of early childhood can still be done through virtual media by giving birth to various kinds of innovations that remain standardized in accordance with government regulations.
\end{abstract}

\section{ABSTRAK}

Pandemik Covid 19 telah menjadi suatu permasalahan tersendiri yang berpengaruh pada seluruh aspek kehidupan manusia di seluruh dunia, termasuk di dalamnya adalah dunia pendidikan. Ketika penerapan PSBB dan penetapan PJJ yang dilakukan pemerintah membuat lembaga-lembaga pendidikan mulai dari jenjang terendah sampai dengan perguruan tinggi harus dapat melaksanakan ketetapan tersebut tanpa melepaskan hak-hak siswa untuk mendapatkan pengajaran. Salah satu solusi yang dapat dilakukan dalam masa pandemik ini adalah penggunaan media sosial yang beragam. Terkait dengan multiple intelegensi anak yang dicetuskan Howard Gardner, bahwa salah satu kecerdasan bahasa anak, akan dseiring dengan kecerdasan kognitifnya. Maka dapat dikatakan dengan penerapan PJJ harus dapat disesuaikan dengan indikator pencapaian sesuai dengan usianya. bebagai macam model dan metode dapat dilakukan, sehingga pertumbuhan dan perkembangan anak usia dini masih dapat dilakukan melaui media virtual dengan melahirkan berbagai macam inovasi yang tetap terstandarisasi sesuai dengan ketetapan pemerintah. 


\section{PENDAHULUAN}

Awal Desember 2019, di Wuhan Cina, terjadi suatu penyebaran penyakit yang banyak mengakibatkan kematian. Penyakit yang menurut penelitian awal disebabkan oleh virus ini , akhirnya menjadi pandemik dunia. Virus yang diberi nama virus "Covid 19" ini oleh WHO (World Health Organization), didiagnosa dengan gejala antara lain demam tinggi disertai dengan pernapasan yang berat sepeti layaknya gejala Pneumonia. Seiring dengan cepatnya penyebaran penyakit ini ke seluruh dunia, penyakit yang dilaporkan terjadi dengan gejala seperti layaknya orang menderita flu disertai dengan kesulitan untuk bernapas, akhirnya didiagnosa bahwa seseorang dapat terkena penyakit ini justru tanpa gejala sama sekali, sehingga penyebaran penyakit ini semakin tidak terdekteksi. Sampai saat ini penyebaran "Covid 19" ini menjadi sesuatu yang sangat serius ditangani dan diselidiki lebih lanjut baik di negara masing-masing, maupun oleh WHO sebagai badan organisasi kesehatan dunia.

Banyaknya faktor kematian membuat hampir semua negara di dunia menerapkan sistem lockdown untuk menekan penyebaran "Covid 19" semakin meluas. Di Indonesia sendiri penerapan lockdown ini dikenal dengan nama Pembatasan Sosial berskala Besar atau disingkat PSBB . PSBB ini diterapkan hampir di seluruh Indonesia yang wilayahnya diprediksi masyarakatnya telah ada yang terkena penyakit ini. Tindakan PSBB mencegah penyebaran virus ini semakin merajalela, tentu saja berdampak sangat besar pada seluruh sendi kehidupan manusia. Selain faktor sosial, ekonomi dan lainnya, bidang pendidikan menjadi salah satu segi kehidupan manusia yang mengalami permasalahan serius di seluruh dunia. Sekolahsekolah harus diliburkan sementara waktu dikarenakan sampai saat ini masih belum ditemukan pencegahan dan pengobatan yang benar-benar efektif untuk menyembuhkan seseorang jika terkena penyakit yang disebabkan oleh virus ini. Lembagalembaga pendidikan yang terimbas dengan penyebaran penyakit ini mulai dari tingkat universitas sampai dengan lembaga-lembaga PAUD. Penerapan sistem pembelajaran jarak jauh atau dikenal degan istilah PJJ , menjadi suatu dilema tersendiri bagi lembaga-lembaga PAUD untuk menyampaikan segala materi pembelajaran bermain yang menyenangkan bagi anak didikmya, termasuk di RA Nurul Huda. Proses pembelajaran yang dilakukan di sekolah diharapkan dapat menstimulasi pertumbuhan fisik dan perkembangan aspek-aspek psidkologis anak secara optimal. Prinsip ini dikemukakan oleh Kuppermint (2001) dan Gettinger (2001) , bahwa hampir seluruh kegiatan anak usia prasekolah perlu melibatkan unusr bermain. Bahwa dengan bersekolah diharpakan akan tumbuh norma sosialnya dan menyadarkan adanya dunia lain selain lingkungan keluarganya, sehingga anak dapat meyesuaikan emosi dan perilakunya, yang berguna bagi kehidupan dewasanya kelak. Berkaitan dengan PJJ yang ditetapkan pemerintah, maka RA Nurul Huda berusaha mencari solusi bagaimanakah sistem 
pembelajaran yang akan digunakan , sehingga aspek tumbuh kembang anak tetap berjalan .

Kecerdasan majemuk menurut Gardner terdiri dari sembilan kecerdasan, yaitu: kecerdasan Verbal-Linguistik, logis matematik, spasial visual, musikal, kinestetik jasmani, naturalis, intrapersonal, interpersonal, dan eksistensial atau sering disebut sebagai kecerdasan spiritual. Sementara dalam Permendikbud No. 137 tahun 2014 , tentang STPPA ( Standar Tingkat Pencapaian Perkembangan Anak), terdapat enam faktor aspek perkembangan yang harus dicapai oleh anak usia dini, yaitu moral dan agama, kognitif, bahasa, fisik motorik, sosial emosional dan seni. Menurut beberapa ahli pendidikan anak usia dini bahwa salah satu aspek kecerdasan anak yaitu bahasa , seiring dengan perkembangan kecerdasan kognitifnya. Maka sorotan kali ini akan ditujukan pada perkembangan aspek bahasa anak di RA Nurul Huda, selama masa pandemik Covid 19 yaitu dengan sistem daring melalui whatsapp messenger dan aplikasi Zoom.

Menurut Piaget tahap belajar anak usia dini berada pada tahap praoperasional. Bahwa anak usia dini pada penerapan pembelajarannya haruslah menggunakan pendekatan konstruktif , yaitu belajar dari pengalaman. Bahwa dengan pengalaman yang anak alami sendiri, maka dia dapat membangun pemahamannya sendiri, sehinga akan terbentuk kearah yang operasional dan semakin nyata. Berdasarkan peraturan PJJ yang ditetapkan pemerintah, maka pihak sekolah harus mencari, sekiranya model pembelajaran apakah yang dapat diterapkan melalui pembelajaran secara daring, sehingga dapat sesuai dengan tahap belajar anak dan dapat memenuhi prinsip konstruktif. Dengan durasi waktu yang terbatas lewat daring, maka pihak sekolah harus memaksimalkan waktu yang efektif, sehingga pencapaian perkembangan yang diharapkan dapat tercapai secara maksimal.

Menurut Vygotsky “ Bahasa memainkan peranan kuat dalam membentuk pemikiran ". Bahasa adalah bentuk komunikasi secara lisan, tulisan, atau tanda yang berdasarkan sistem simbol. Berbahasa berkaitan dengan proses berpikir, bahwa ketika kita berbicara maka akan menyangkut logika. Bagaimana seseorang merangkai urutan peristiwa menjadi suatu informasi yang akan disampaikan, tentu saja memerlukan kata yang tepat sehingga dapat dimengerti oleh orang lain, proses pemilihan kata yang tepat ini memerlukan keterampilan berpikir. Keterampilan berbahasa perlu diasah terusmenerus, layaknya tubuh yang memerlukan makanan bergizi untuk tumbuh dan berkembang dengan baik. Potensi ini akan tinggal potensi jika tidak dilatih dan dikembangkan. Tentu saja hal ini menjadi tugas orang tua dan juga guru di sekolah, sehinga pengetahuan tentang perkembangan bahasa anak sangatlah diperlukan

Perkembangan bahasa dipengaruhi oleh faktor biologis dan juga lingkungan. Untuk faktor biologis, anak sudah siap belajar bahasa saat mereka melakukan interaksi, dan lingkungan ikut serta mempengaruhi, 
seperti lingkungan rumah dan sekolah. Tahapan dalam perkembangan bahasa menurut Dworetzsky (1990) terdiri dari tahap pralinguistik dan tahap linguistik. Maka terkait dengan apa yang dikemukakan oleh Dworetzsky, maka terkait dengan perkembangan bahasa anak yang dipengaruhi lingkungan, pihak sekolah akan memanfaatkan hal tersebut untuk dituangkan dalam pembelajaran secara daring .

\section{METODOLOGI PENELITIAN}

Penelitian ini menggunakan metode kualitatif yang bersifat deskriptif analitis yang menggunakan data kepustakaan (library research), yang dilakukan dengan membaca dan mempelajarai buku-buku yang berhubungan dengah pertumbuhan dan perkembangan anak usia dini . langkah yang dilakukan dalam penelitian ini adalah langkah deskriptif, yaitu menggambarkan atau menguraikan permasalahan yang diteliti.

Perangkat komputer beserta download aplikasi zoom, serta penggunaan alat komunikasi Handphone menjadi sarana yang diperlukan untuk melakukan pembelajaran secara daring. Persiapan kuota internet dilakukan pihak sekolah, untuk menunjang kelancaran proses pembelajaran. Mempelajari penggunaan aplikasi zoom dan juga Whatsapp messenger secara maksimal juga dilakukan , agar mendapatkan hasil dan implikasi yang diharapkan sesuai dengan target pencapaian yang ditetapkan.
Media belajar disiapkan sesuai tema yang akan disampaikan pada pembelajaran secara daring, dan pihak orang tua diharapkan bekerjasama, dengan menyediakan sarana dan prasarana yang disarankan pihak sekolah, sehinga tercapai tujuan yang diharapkan, yaitu keberlangsungan pembelajaran dalam masa PJJ secara daring. Durasi waktu yang dipergunakan pada penggunaan aplikasi zoom adalah selama empat puluh menit maksmal, dengan waktu durasi tigapuluh menit penyampaian materi Inti sesuai tema. Adapun penggunaan aplikasi whatsapp messenger dipergunakan untuk pelaporan hasil belajar anak berbentuk visual, maupun audio visual, dengan batas pelaporan setelah pembelajaran secara daring berlangsung, hingga batas waktu pembelajaran normal sesuai waktu pembelajaran secara normal seperti biasanya di sekolah.

\section{HASIL DAN PEMBAHASAN}

\section{A. Multiple Intellengences}

Howard Gardner memandang kecerdasan manusia dengan mengukur tiga kemampuan sebagai berikut:

(1). Kemampuan menyelesaikan masalah yang terjadi dalam kehidupan sehari-hari;

(2). Kemampuan menghasilkan persoalan-persoalan baru yang dihadapi untuk diselesaikan;

(3). Kemampuan menciptakan sesuatu atau menawarkan jasa yang diharapkan akan menimbulkan 
penghargaan dalam budaya
seseorang.
Teori Multiple Intellegences
dikemukakan oleh Gardner
berdasarkan pandangannya bahwa
kecerdasan sebelumnya hanya
dilihat dari segi linguistik dan logika
saja, sementara kecerdasan lainnya
tidak diperhatikan. Multiple
intelengences melihat secara
deskriptif individu rang
menggunakan kecerdasannya untuk
memecahkan masalah dan
menghasilkan sesuatu. Selain
potensi yang ada pada diri
seseorang, kecerdasan juga berkaitan dengan peran otak. Semua gerakan yang dilakukan manusia diatur oleh otak. Setiap belahan otak ( hemisphere ) mengontrol gerakan tubuh yang berlawanan. Belahan otak kiri mengatur badan, mata, dan telinga bagian kanan, juga berperan dominan dalam berpikir logis dan rasional, menganalisa, bicara, serta berorientasi pada waktu dan hal-hal yang terinci. Sementara belahan otak kanan mengontrol badan, mata, dan telinga bagian kiri, juga dominan untuk hal-hal yang intuitif, merasakan, bermusik, menari, melakukan hal-hal kreatif dan sebagainya. Kecerdasan majemuk menurut Gardner terdiri dari sembilan kecerdasan, yaitu: kecerdasan Verbal-Linguistik, logis matematik, spasial visual, musikal, kinestetik jasmani, naturalis, intrapersonal, interpersonal, dan eksistensial atau sering disebut sebagai kecerdasan spiritual.

\section{B. Kemampuan Berbahasa}

Pandai berbicara, menyimak cerita, menceritakan kembali adalah beberapa ciri anak yang memiliki kecerdasan linguistik atau kecerdasan bahasa. Hal ini tidak terjadi dengan sendirinya, tetapi tentu saja melewati suatu proses perkembangan. Menurut Vygotsky “ Bahasa memainkan peranan kuat dalam membentuk pemikiran ". Bahasa adalah bentuk komunikasi secara lisan, tulisan, atau tanda yang berdasarkan sistem simbol. Berbahasa berkaitan dengan proses berpikir, bahwa ketika kita berbicara maka akan menyangkut logika. Bagaimana seseorang merangkai urutan peristiwa menjadi suatu informasi yang akan disampaikan, tentu saja memerlukan kata yang tepat sehingga dapat dimengerti oleh orang lain, proses pemilihan kata yang tepat ini memerlukan keterampilan berpikir.

Keterampilan berbahasa perlu diasah terus-menerus, layaknya tubuh yang memerlukan makanan bergizi untuk tumbuh dan berkembang dengan baik. Potensi ini akan tinggal potensi jika tidak dilatih dan dikembangkan. Tentu saja hal ini menjadi tugas orang tua dan juga guru di sekolah, sehinga pengetahuan tentang perkembangan bahasa anak sangatlah diperlukan

Perkembangan bahasa manusia mengikuti aturan fonologi, morfologi, sintaksis, semantik, dan pragmatis. David Lewis penulis buku "The Secret Languange of Your Child", mengatakan bahwa kemampuan manusia untuk membentuk perbendaharaan kata yang rumit, sintaksis dan tata bahasa suatu kalimat, sebagian besar dibawa dari lahir yang lebih mengandalkan kekuatan otak daripada organ bicara. Fonologi adalah sistem suara bahasa, morfologi adalah aturan untuk mengombinasikan morfem 
yang merupakan rangkaian suara, sintaksis adalah cara kata yang dikombinasikan untuk membentuk frasa dan kalimat yang bisa dipahami, sintaksis adalah cara kata dikombinasikan menjadi frasa atau dua kalimat yang dapat dipahami, semantik adalah arti dari kata atau kalimat, dan pragmatis adalah penggunaan percakapan yang tepat. Sehingga standar pencapaian perkembangan anak haruslah dilalui sesuai urutan dan terstimulasi dengan maksimal pada setiap tahapannya. Dengan demikian kecerdasan berbahasa ini sangat penting dilakukan sejak usia dini.

\section{Perkembangan Bahasa menurut Dworetzsky}

Tahap pralinguistik adalah sejak bayi lahir, sampai dengan akhir masa bayi atau sekitar usia sebelas bulan , ketika mereka telah mampu memberikan respon atau melakukan gerakan yang positif saat berkomunikasi . Pada masa ini anak belum mengenal bahasa atau mampu berbahasa, bahwa bayi yang baru saja lahir tidak dapat mengenal bahasa yang orang tuanya katakan dan bayi tidak mampu berbahasa, seperti yang orang tuanya katakan, tetapi bayi dapat membuat bahasanya sendiri dan tidak dimengerti orang tuanya. Pada tahapan linguistik, anak sudah mulai tampak perkembangan bahasanya dan sudah mulai mampu menggunakan kata-kata dalam berbicara. Kata yang dimaksud adalah ucapan yang berhubungan langsung dengan benda atau kegiatan tertentu,sebagai bentuk dasar, misalnya mama, papa, baba dan baru kemudian mempelajari kata abstrak. Perkembangan dan perbendaharaan kata semakin banyak dan meningkat, dan pada usia 5-6 tahun anak dapat menguasai dan menggunakan sekitar 2.500 kata, dan mengerti sekitar 6.000 kata.

Berikut adalah tahap pralinguistik, Dua minggu, menangisnya mulai berkurang dan mulai memberikan gerak dan isyarat acak;

(1) Enam minggu, anak mulai membuat suara seperti "uuhh", dan menjerit;

(2). Tiga sampai enam bulan, membuat vokal konsonan dan mulai mengoceh;

(3). Enam sampai Sembilan bulan, anak membuat suara seperti “ as, ah, ba, ba" meniru suara asidental dan lebih banyak mengulang kata silabel/suku kata ;

(4). Sembilan bulan sampai sebelas bulan, anak, menunjukkan tanda pasti dari pemahaman beberapa kata dan perintah sederhana dan meniru suara deliberasi/ kata yang memiliki arti.

Yang kedua adalah periode linguistik yaitu kata pertama kali diucapkan anak pada akhir masa bayi. Kata pertama umumnya terjadi pada usia 10-17 bulan. Kata pertama yang diucapkan biasanya berhubungan langsung dengan benda atau kegiatan tertentu sebagai bentuk dasar, misalnya mama, papa, baba, dan baru kemudian mempelajari kata abstrak. Berikut tahapan linguistik :

(1). Tahapan pertama yaitu ucapan satu kata dari usia 1-2 tahun (awal tahun duabelas sampai delapanbelas bulan) . Ciri perkembangannya adalah : anak 
menggunakan holofrase/holofrastik , kosa kata terdiri dari tiga sampai enam kata, intonasi kompleks menggunakan kata benda yang luas, dan menggunakan kosakata yang terdiri dari: 3-50 kata dan anak tidak merasa lelah meskipun tidak memahami . Pengucapan beberapa kata sudah konsisten, tetapi cara pengucapan bervariasi. Dapat menggunakan satu kata untuk meyebut benda tertentu, dan dapat mengemukakan makna yang berhubungan dengan benda tersebut. cara berkomunikasi masih megekspresikan keinginan dan megarahkan perilakunya pada orang lain.

(2). Tahapan kedua yaitu membuat kata-kata dalam frase dari usia 2-3 , dan ciri perkembangannya adalah : anak menggunakan bahasa telegraphic yang terdiri dari 2-3 kata, kosakata yang digunakan terdiri dari 3-50 kata, anak mengalami peningkatan dalam berkomunikasi dan mulai menggunakan percakapan, terkadang dengan mempertimbangkan periode percepatan dalam perkembangan bahasa, kosakata dapat bertambah setiap hari yakni 200-300 kata, dan anak berusaha untuk berkomunikasi dan tidak menunjukan rasa frustasi meski tidak memahami apa yang diucapkannya. Cara berbahasa mulai mengikuti aturan aturan tata bahasa secara konsisten. Artikulasi sebagian besar konsonan dapt diucapkan dengan baik ( "r" dan " $s$ ") . keterngan waktu seperti "kemarin", "tadi", kata ganti orang seperti " dia", "kamu", "mereka", mulai digunakan. Dalam cara berbicara sudah dapat berusaha menjadi lawan bicara yang baik, dan sudah dapat berdialog secara singkat. Sudah dapat menggunakan istilah "disini", " di mana", atau kalimat tanya jawab , untuk mengarahkan perhatian dan mendapatkan pertolongan yang dia inginkan . Anak dalam usia ini sudah dapat menggunakan sudut pandamg lawan bicaranya.

(3). Tahapan ketiga yaitu menggunakan kalimat secara lengkap dari usia 4-6 tahun. Ciri perkembangannya adalah : penerapan pengucapan dan tata bahasa, bahasa terdiri dari 14001600 kata, anak mencari cara memahami kata yang tidak dimengerti, mulai dengan menyesuaikan pengucapan untuk yang mendengarkan informasi yang disampaikannya, mengalami perselisihan dengan kawan sebaya dan kata ajakan untuk lebih sering bermain, kemudian susunan kalimat mulai menggunakan tata bahasa yang benar. Secara bahasa dapat mengucapkan sekumpulan konsonan secara menyatu seperti kata " praktis", "semprong ", “ semrawut", dan lainnya. Dalam komunikasi dapat menggunakan kata yang lebih sederhana, dan dapat mengungkapkan perasaannya ( sudah memilki kepedulian sosial ataupun empati ).

(4). Tahapan keempat yaitu menggunakan bahasa secara simbolik (membaca dan menulis) dari usia 6-8 tahun, menggunakan bahasa yang lebih kompleks jumlah kata-kata perkalimat enam sampai tujuh kata, kosa kata untuk bahasa lisan sekitar tigaribu kata dan lebih cenderung menggunakan kata kerja yang dibendakan. 
D. Pelaksanaan pembelajaran secara daring

Rencana Pelaksanaan Pembelajaran (RPP) merupakan rancangan bagi guru untuk melaksanakan kegiatan bermain yang mendukung anak dalam proses belajar. RPP berisi langkah-langkah konkret yang dilakukan oleh guru agar proses pembelajaran berlangsung dengan baik, dimana penyusunannya dapat mengacu pada karakteristik anak maupun aspek yang akan dikembangkan. Proses pembelajaran harus dapat menarik minat anak dan membantu meningkatkan seluruh aspek perkembangannya dan diantaranya adalah aspel bahasa. RPP yang disusun guru selama masa pandemi covid 19 dirancang sangat sederhana berbeda dengan RPP yang dirancang untuk situasi normal. RPP belajar di rumah hanya berisi kegiatan-kegiatan bermain yang memberikan pengalaman belajar bermakna bagi anak tanpa terbebani tuntutan untuk menuntaskan capaian pembelajaran sesuai . Kegiatan bermain yang disusun dan difokuskan pada keterampilan hidup seperti halnya keterampilan bahasa. Selama masa daring RA nurul Huda menerapkan SOP (Standar operasional pelaksanaan ) pembelajaran sebagai berikut :

(1). Guru menyiapkan peralatan untuk pemberian materi secara daring, yaitu: cek kesiapan kuota dan jaringan, menyiapkan laptop/komputer, menyiapkan materi rpp, menyiapkan media belajar untuk daring,mengkondisikan kesiapan siswa dan orang tua di rumah,

(2). Guru menyambungkan koneksi pembelajaran secara daring. Setelah tersambung lewat daring, guru membuka kegiatan dengan mengucapkan salam, menyapa anak, menanyakan kabar dan lainlain.

(3) . Guru membimbing siswa untuk: membaca Al fatihah dipimpin oleh guru, membaca do'a sehat dan artinya,membaca do'a belajardan artinya,mengucapkan salam.

(4). Guru menyampaikan materi inti

(5). Guru melakukan review .

(6). Guru memberikan penugasan Pendidikan karakter pada siswa.

(7). Guru menutup kegiatan pembelajaran daring dengan membacakan do'a akhir majelis dan salam.

Pada bagian materi inti, penekanan pada aspek bahasa dikembangkan lewat RPP ( Rencana Pelaksanaan Pembelajaran) dengan contoh sebagai berikut :

Tema : Kendaraan

Sub tema :Kendaraan

Udara/Pesawat Terbang

Semester : 2/April/2020

Kelompok : A ( usia 4-5 tahun )

NAM : anak dapat mengucapkan do'a naik kendaraan

Motorik kasar : anak dapat menirukan gerakan pesawat terbang dan sambal meirukan suara pesawat terbang.

Motorik halus: anak dapat megekspresikan diri lewat gambar pesawat sesuai imajinasinya dan dapat menceritakan gambar yang dibuatnya

Kognitif : anak dapat bermain secara simbolik menggunakan benda disekitarnya sambal bercerita pengalamannya naik pesawat terbang

Bahasa: anak dapat mengungkapkan persaanya seandainya naik pesawat terbang dengan aturan protocol kesehatan 
Sosial emosional : anak dapat menunjukkan rasa antusias ketika menceritakan pengalaman belajar pada hari ini.

Penugasan: orang tua dapat menceritakan kisah tentang pesawat terbang dikaitkan dengan keadaan pandemik covid 19.

Salah satu contoh RPP diatas dapat disesuaikan dengan apa yang disampaikan oleh Dworetzky antara lain bahwa dalam komunikasi anak dapat menggunakan kata yang lebih sederhana, dan dapat mengungkapkan perasaannya , serta sudah memiliki kepedulian sosial ataupun empati .

Berikutnya tahap perkembangan bahasa anak dapat distimulasi dengan berbagai macam cara, antara lain : lewat bercerita yang dilakukan orang tua di rumah berdasarkan arahan dari guru, membiarkan anak bercerita tentang pengalamananya sehingga dapat merangsang anak mengembangkan keterampilan berbicaranya di rumah,ataupun berdiskusi sederhana antara orang tua dan anak misal tentang pengalamannya pergi ke sekolah dalam kondisi pandemik dan kegiatan lainnya.

\section{SIMPULAN}

Dalam kondisi pandemik Covid 19, tidaklah menjadikan suatu halangan dalam suatu pembelajaran yang dibatasi dengan aturan PJJ yang ditetapkan pemerintah. Kreatifitas guru serta penguasaan kompetensi lainya, menyangkut penguasaan paedagogik serta wawasan belajar yang didalamnya disertai dengan keikhlasan akan tugasnya sebagai pendidik, akan menjadikan suatu motivasi bagi pendidik mencari solusi, sehingga masa-masa golden Age pada siswanya tidak akan terlewati dengan sia-sia. Dengan penguasaan STPPA dan juga menguasai teknologi sederhana, dapat menjadi satyu solusi yang menimbulkan suatu inovasi baru dalam suatu proses pembelajaran, sehingga tidak akan terhalang oleh sekat apapun. Perkembangan bahasa anak yang dilakukan di RA Nurul Huda selama masa pandemik lewat pembelajaran virtual diharapkan dapat menjadi salah satu stimulasi juga untuk kecerdasan kognitifnya, sehingga pekembangan yang sesuai sengan usinay masih dapat dicapai .

\section{DAFTAR PUSTAKA}

Prof. Dr. H. Achmad Juntika Nurihsan, M.Pd, Dr. H. Mubiar Agustin, M.Pd. 2016, Dinamika Perkembangan Anak Dan Remaja, Tinjauan Psikologi , Pendidikan, Dan Bimbingan, Refika Aditama Bandung.

Dr. Hj. Erhamwilda, Dra., M.Pd. , 2018, Psikologi Belajar Islami, Dilengkapi Dengan Pendidikan Seks Bagi Anakanak Usia Dini, Psikosain Yogyakarta.

Immanuella F.rachmani, Andi Maerzyda A.D. Th, Grahita Purbasantika Nugraha, Cherry Riadi Lukman, Dewi handadjani Poedianto, 2003, Multiple Intelegences, seri Ayabbunda, mengenali dan merangsang potensi kecerdasan anak, Aspira Pemuda,Jakarta.

Reni Akbar Hawadi, 2001, Psikologi Perkembangan Anak, Mengenal Sifat, Bakat, dan Kemampuan Anak, Grasindo, Jakarta .

Dr. M. Solehuddin, M.Pd, 2018, Pendidikan Anak Usia Dini , Gapura Press, Bandung . 
Dr. Rita Eka Izzaty, M.Si., Psi, 2014, Perilaku Anak Prasekolah, Masalah dan Cara Menghadapinya, Elex media Komputindo, Jakarta.

Djoko Adi waluyo, Anies Listyowati, 2002, Kompedium PAUD, Memahami PAUD Secara Singkat, Prenada Media Group, Depok.

Mhd. Habibu Rahman, M.Pd., dkk, 2019, Model Model Pembelajaran Anak Usia Dini, Teori dan Implementasi, Ar- Ruzz media, Yogyakarta. 